\title{
PERANAN PENEGAK HUKUM TERHADAP HAK CIPTA KARYA MUSIK DALAM BENTUK JUAL BELI VCD BAJAKAN DI KABUPATEN LABUHANBATU UTARA
}

\author{
Indra Kumalasari $\mathbf{M}^{1}$ \\ indrakumalasarim@gmail.com
}

\begin{abstract}
The copyright protection of music released in VCD form is a royalty rights of the songwriter. Legislation on Intellectual Property Rights is stipulated in the Copyright Act Number 28 of 2014. Piracy is the Unauthorized Copy of Works and / or Related Rights products and the distribution of such multiplication products widely to obtain economic benefits. The role of law enforcement in Labuhanbatu Utara District is needed to protect the copyrights of music works, however, the police officers never conduct regular raids against pirated dealers and sellers of VCDs. There are many actors who influence the rampant dealer and the sale of pirated VCDs in Labuhanbatu Utara Regency is a factor of law enforcement officers and community factors who prefer to buy pirated VCDs than the original VCD because the price is cheaper.
\end{abstract}

Keywords: Copyright, Musical Works, Pirated VCDs

\section{PENDAHULUAN}

\subsection{Latar Belakang}

Negara adalah suatu organisasi yang meliputi wilayah, sejumlah rakyat dan mempunyai kekuasaan berdaulat. Negara Indonesia adalah negara hukum ${ }^{2}$. Hal ini dinyatakan dalam Pasal 1 ayat (3) UndangUndang Dasar 1945. Menurut H.M Tirtaatmidjaja Hukum adalah keseluruhan aturan atau norma yang harus diikuti dalam berbagai tindakan dan tingkah laku dalam pergaulan hidup. Bagi yang melanggar hukum akan dikenai sanksi, Denda, Kurungan, Penjara atau sanksi lainnya. ${ }^{3}$ Menurut penulis hukum merupakan bagian dari sistem yang memiliki bagian suatu kesatuan yang terdiri dari unsur-unsur yang mempunyai interaksi satu sama lain dan bekerja sama untuk mencapai tujuan tersebut.

Perkembangan dan kemajuan sistem informasi dan teknologi pada kenyataanya membernikan dampak yang signifikan kepada kemajuan teknologi diberbagai bidang kehidupan manusia. Semakin berkembangnya sistem informasi dan teknologi maka semakin tinggi tingkat kerawanan akan perdagangan barang palsu/bajakan. Salah satu contoh barang bajakan adalah VCD bajakan. Dengan kemajuan teknologi maka seseorang dapat menggandakan

${ }^{1}$ Dosen Ilmu Hukum di Sekolah Tinggi Ilmu Hukum Labuhan Batu 
suatu karya intelektual dengan tanpa harus meminta ijin dari pemegang hak cipta. Perkembangan dan kemajuan teknologi yang sangat pesat ini juga semakin mempermudah proses pembuatan cakram optic sehingga berdampak pada penyalahgunaan perkembangan dan kemajuan teknologi oleh pihak-pihak yang memang berhak atas royalti dari hasil karya/kreatifitas mereka ${ }^{4}$.

Hak Kekayaan Intelektual (selanjutnya disebut dengan $\mathrm{HKI}$ ) atau biasa disebut juga Hak Milik Intelektual adalah padanan kata dari Intellectual Property Rights. Ada 2 kategori HKI. Pertama adalah pengertian HKI dalam istilah seharihari yaitu segala sesuatu yang berasal dari hasil pemikiran manusia seperti ide, invensi, puisi, merek, desain, semi konduktor dan sebagainya. Kedua adalah pengertian HKI dalam konsep hukum yaitu seperangkat aturan hukum yang memberikan jaminan hak eksklusif untuk mengeksploitasi HKI dalam jangka waktu tertentu berdasarkan jenis-jenis HKI. Hak cipta secara khusus juga berfungsi sebagai alat untuk memperkenalkan, memperkaya dan menyebarluaskan kekayaan budaya bangsa ${ }^{5}$.

Salah satu jenis HKI adalah hak cipta karya musik yang dikemas dalam bentuk VCD yang distribusinya biasanya di toko kaset yang menjual kaset dan VCD asli. Lagu masuk dalam ranah HKI yang dilindungi sebagaimana diatur dalam Pasal 58 huruf (d) Undang-undang Nomor 28 Tahun 2014 tentang Hak Cipta (UUHC) yaitu Perlindungan Hak Cipta atas Ciptaan lagu atau musik dengan atau tanpa teks.

Sebagaimana dilindungi oleh UUHC maka pencipta lagu berhak atas hak ekonomi atas hasil karya ciptaannya. Hak ekonomi ini diperlukan sebagai bentuk apresiasi atau nilai atas hasil kreatifitas dari ciptaannya yang berupa lagu yang dapat dinikmati oleh masyarakat atau orang ketika mendengarkannya. Artinya pencipta berhak atas hak ekonomi dari lagu yang dinikmati oleh masyarakat ${ }^{6}$.

Keberadaan Undang-undang ini tentunya memberikan dimensi baru sebuah dimensi tugas baru bagi Kepolisian sebagai salah satu bagian dari Criminal Justice System terutama dalam upayanya melakukan
4 http://www. Ferli1982.wordpress.com. diakses 23 september 2017, pukul 5.02 PM

5 Kusmawan Denny, 2014, Perlindungan Hak Cipta Atas Buku, Jurnal Perspektif, Vol. 2. Hal.321
${ }^{6}$ Kusno, Habi, 2016, Perlindungan Hukum Hak Cipta Terhadap Pencipta Lagu yang Diunduh Melalui Internet, Jurnal Fiat Justicia, Vol. 10. Hal. 456 
perlindungan Hak Cipta. Sampai saat ini, yang sering dilakukan oleh penegak hukum, khususnya Kepolisian atas keberadaan HKI dalam upaya penegakan hukum untuk menghentikan secara kilat kegiatan pembajakan masih berada pada sektor hilir dan pada sektor menengah. Contohnya Polres Bojonegoro pada tahun 2016 melakukan razia maraknya penjualan VCD bajakan dan menyita sebanyak 1505 keping VCD dan DVD bajakan ${ }^{7}$. Kenyataan di lapangan, terdapat kesulitan mencapai dan menemukan produsen atau aktor intelektual yang berperan sebagai orang yang memproduksi VCD bajakan yang memberikan kesan penegakan hukum atas kejahatan hak cipta.

Kabupaten Labuhanbatu Utara tidak ditemukan adanya kegiatan pembajakan kaset maka hal yang paling tampak dan nyata yang bisa dilihat ialah pengedar dan penjual kaset VCD bajakan yang banyak ditiap sudut daerah kabupaten labuhanbatu utara padahal mereka sudah mengetahui bahwa sudah ada Undang-Undang yang melarang peredaran VCD bajakan namum hal

7 http://www.beritabojonegoro.com. Diakses tanggal 1 desember 2017, pukul : 05.15 PM

8 Wawancara dengan Penjual Kaset CD/ VCD Original di Toko ET.45 Sun Plaza Medan

9 Wawancara dengan rahmad, pembeli VCD Bajakan, Senin Tanggal 28 November 2017, Bertempat Di Aek Kanopan itu tidak cukup membuat mereka takut untuk tetap berjualan VCD bajakan. Salah satu hal yang membuat para pedagang tetap mau berjualan VCD bajakan juga disebabkan alasan ekonomi, karena para pembeli kaset lebih suka membeli VCD bajakan, daripada harus membeli yang original. Hal ini disebabkan perbedaan harga antara VCD original dengan bajakan (Tabel 1).

Tabel 1.

Perbedaan Harga VCD Original dan Bajakan

\begin{tabular}{|c|c|c|}
\hline No & $\begin{array}{c}\text { Type } \\
\text { Barang }\end{array}$ & $\begin{array}{c}\text { Harga Jual } \\
\text { per Keping }\end{array}$ \\
\hline 1. & $\begin{array}{c}\text { Kaset } \\
\text { CDVCD } \\
\text { Original }\end{array}$ & $\begin{array}{c}\text { Rp. } 20.000,- \\
\text { s/d 160.000,- }\end{array}$ \\
\hline 2. & $\begin{array}{c}\text { Kaset CD/ } \\
\text { VCD } \\
\text { Bajakan }\end{array}$ & $\begin{array}{c}\text { Rp. } 7.000- \\
\text { s/d, }-{ }^{-} 8000\end{array}$ \\
\hline
\end{tabular}

sumber: Hasil Wawancara Penjual VCD bajakan Tahun $2017^{10}$

Tujuan penegakan hukum yakni untuk mengatur masyarakat agar damai dan adil dengan mengadakan keseimbangan antara kepentingan yang dilindungi,sehingga tiap-tiap anggota masyarakat memperoleh sebanyak mungkin apa yang menjadi haknya $^{11}$. Peranan penegak hukum terhadap pengedar dan penjual VCD bajakan di wilayah Hukum Polisi

1o Wawancara dengan saudara dengan insial Fi dan Jn, Pedagang VCD bajakan, Hari Selasa 27 November 2017, Bertempat di Aek Kanopan.

11 RE. Baringbing. 2001. Catur Wangsa Simpul Mewujudkan Supremasi Hukum, Jakarta: Pusat Kajian Informasi, hal. 54 
Resort Kabupaten Labuhanbatu Utara sangat jauh dari harapan, ini bisa dilihat dengan semakin banyak munculnya penjual VCD bajakan di setiap daerah dan terkesan adanya "Pembiaran" oleh pihak polisi karena penjual VCD bajakan ada yang berjualan di sekitar kantor polisi tapi tidak ada inisiatif dari pihak polisi untuk melakukan razia ataupun peringatan kepada penjual VCD bajakan. Oleh karena itu diperlukan penanganan serius agar tindak pidana pengedar dan penjual VCD bajakan di wilayah hukum Polisi Resort Kabupaten Labuhanbatu Utara dapat ditegakkan sehingga apa yang menjadi tujuan daripada UndangUndang Nomor 28 tahun 2014 tentang Hak Cipta dapat tercapai.

\subsection{Rumusan Masalah}

Berdasarkan latar belakang di atas maka permasalahan yang akan dibahas dalam penelitian ini adalah :

1. Bagaimana peranan penegak hukum dalam melindungi Hak Cipta Karya Musik khususnya VCD bajakan di Kabupaten Labuhanbatu Utara?

2. Apa faktor-faktor yang mempengaruhi maraknya jual beli VCD bajakan di Kabupaten Labuhanbatu Utara.

\subsection{Tujuan dan Manfaat Penelitian}

1. TujuanPenelitian Terkait dengan judul dan permasalahan yang dikemukakan dalam penelitian ini, maka tujuan penelitian ini yaitu sebagai berikut:

a. Untuk mengetahui dan menganalisis pengaturan hukum tentang bentuk VCD Bajakan di kabupaten Labuhanbatu Utara.

b. Untuk Mengetahui dan menganalisis faktor- faktor yang mempengaruhi maraknya jual VCD bajakan dikabupaten Labuhanbatu Utara.

2. Manfaat Penelitian

Diharapkan penelitian ini dapat memberi manfaat yang bersifat praktis maupun teoritis. Secara Teori Akademis, Hasil Penelitian ini memberi masukan dan sumbangan pikiran dalam rangka penyusunan perundang-undangan yang berkaitan dengan Hak Cipta Karya Musik Dalam Bentuk Jual Beli VCD Bajakan. Secara praktis, hasil penelitian ini dapat memberi manfaat untuk kepentingan penegak hukum, sehingga dapat dijadikan masukan dalam cara berpikir dan cara bertindak dalam penegakan hukum untuk mewujudkan tujuan hukum dalam 
pemberantasan jual beli VCD bajakan.

\section{KERANGKA TEORITIS}

Teori yang dipergunakan sebagai pisau analisis atas permasalahan penelitian ini adalah Teori Keadilan, Berdasarkan pada perkembangan pemikiran filsafat hukum dan teori hukum, tentu tidak lepas dari konsep keadilan. Konsep keadilan tidak menjadi monopoli pemikiran satu ahli saja, namun penulis mengambil salah satu pendapat ahli yang menjadi rujukan dalam penelitian ini yaitu Teori Keadilan yang dikemukakan oleh Aristoteles yang menyatakan bahwa keadilan ialah tindakan yang terletak diantara memberikan terlalu banyak dan juga sedikit yang dapat diartikan ialah memberikan sesuatu kepada setiap orang sesuai dengan memberi apa yang menjadi haknya ${ }^{12}$.

Teori Keadilan yang dimaksud disini adalah keseimbangan artinya hak ekonomi si pencipta yang sebagaimana diatur dalam undang-undang Nomor 28 Tahun 2014 tentang Hak Cipta dan bagi masnyarakat pembeli VCD yang Original sebagai penikmat musik. Pencipta karya musik telah membuatnya dalam bentuk VCD yang diperjual belikan kepada masyarakat dengan tujuan untuk memperoleh keuntungan ekonomis, namun disini telah terjadi pelanggaran hukum berupa pembajakan VCD yang mengakibatkan kerugian ekonomis bagi sipencipta, hal ini disebabkan karena pelaku-pelaku pembajakan VCD semakin marak terjadi khususnya di daerah kabupaten labuhanbatu utara yang dengan sengaja memperbayak isi musik kedalam bentuk VCD dan tanpa izin dari si pencipta. Maraknya jual beli VCD Bajakkan ini disebabkan ada beberapa faktor yang menjadi kendala- kendala diantaranya yaitu faktor ekonomi, faktor budaya masyarakatnya, faktor aparat penegak hukum dan faktor pendidikan.

III. HASIL PENELITIAN DAN PEMBAHASAN

\subsection{Peranan Penegak Hukum Tentang Hak Cipta Karya Musik}

Hak cipta berisikan hak ekonomi (economic right) dan hak moral (moral right). Hak ekonomi adalah hak untuk mendapatkan manfaat ekonomi atas Ciptaan serta produk Hak terkait. Sedang hak moral adalah hak yang melekat pada diri Pencipta atau Pelaku yang tidak dapat dihilangkan atau dihapus tanpa alasan apapun, walaupun Hak Cipta atau Hak Terkait telah dialihkan ${ }^{13}$. 
UUHC mengatur mengenai penegakan hukum hak cipta melalui instrumen hukum pidana dan hukum perdata. Instrumen pidana dalam pemanfaatan hak cipta lagu di internet atau mengunduh lagu di internet sebagaimana yang diatur dalam UUHC Pasal 113 Ayat (3) yang menyatakan: .

Setiap Orang yang dengan tanpa hak dan/atau tanpa izin Pencipta atau pemegang Hak Cipta melakukan pelanggaran hak ekonomi Pencipta sebagaimana dimaksud dalam Pasal 9 ayat (1) huruf $a$, huruf $b$, huruf $e$, dan/atau huruf $g$ untuk Penggunaan Secara Komersial dipidana dengan pidana penjara paling lama 4 (empat) tahun dan/atau pidana denda paling banyak Rp1.000.000.000,00 (satu miliar rupiah $)^{14}$.

Indonesia sekalipun dengan berlakunya Asean Free Trade Area (AFTA) dan Agreement on Trade Related Aspects of Intelectual Property Rights, Including Trade on Counterfeit Goods(TRIPs) telah memaksa Indonesia untuk menyelaraskan (ratifikasi) peraturan perundang-undangan di Indonesia di bidang Hak Kekayaan Intrelektual dengan konvensi Internasional. Masih juga belum dapat memenuhi kewajibannya dalam mencegah pembajakan Hak Kekayaan

Intelektual khususnya dalam bidang Hak Cipta, bahkan tindakan pelanggaran ini seolah-olah dapat dikatakan suatu tindakan legal, sebagai contoh apabila kita berkeliling jalan-jalan di Mall ataupun dipasar-pasar tertentu kita mungkin melihat pedagang yang menjual ataupun menyewakan VCD bajakan secara terang-terangan, padahal ini adalah suatu bentuk pelanggaran Hak Cipta akan tetapi hal ini tampaknya biasa saja bagi kita ${ }^{15}$.

Tindakan preventif yang dapat dilakukan adalah dengan memberikan penyuluhan kepada hukum kepada pengedar dan penjual VCD bajakan dan memberi pengertian mengenai perbuatan mereka adalah perbuatan yang melanggar hukum pidana dan ancaman yang bisa dijatuhkan pada mereka adalah pidana penjara dan denda, tetapi pihak kepolisian tidak pernah melakukan tindakan ini sehingga para penjual VCD bajakan merasa bebas untuk terus melakukan perbuatan yang melanggar hukum.

Tindakan Hukum Represif juga dapat dilakukan dengan tujuan untuk memulihkan kembali keadaan sebelum terjadinya tindak pidana.
14 Undang-Undang Nomor 28 Tahun 2014 Tentang Hak atas Kekayaan Intelektual

15 Thalib Prawitri, 2013, Perlindungan Hukum Terhadap Pemegang Hak Cipta dan Pemilik Lisensi Rekaman
Berdasarkan Undang-undang Tentang Hak Cipta, Jurnal Yuridika, Vol. 28. No. 3. Hal. 353-354

Jurnal Ilmiah "Advokasi" Vol. 06. No. 01 Maret 2018 
Adapun tindakan represif yang bisa dilakukan oleh pihak Kepolisian Kabupaten Labuhanbatu Utara adalah dengan melakukan razia ke ruko dan kedai yang diduga menjual VCD bajakan, penyidik dapat melakukan razia minimal $2 x$ setahun, yang mana para aparat Kepolisian Resort Kabupaten Labuhanbatu Utara biasanya melakukan razia pada bulan Ramadhan dan Desember. Namun fakta dilapangan menunjukkan bahwa pihak kepolisian tidak pernah melakukan razia kepada pengedar ataupun penjual VCD bajakan. Hasil wawancara menyatakan bahwa para Kepolisian Kabupaten Labuhanbatu Utara tidak pernah melakukan razia selama mereka berjualan.

Pembiaran ini terus terjadi karena pihak polisi tidak tegas dalam menangani pelanggaran hak cipta. Rendahnya hukuman yang diberikan kepada pelanggar Hak Cipta menandakan penegakan hukum terhadap pelaku pelanggaran merupakatan faktor utama lemahnya penegakan hukum di bidang Hak Cipta. Para penegak hukum seolaholah tidak mau mengurusi pembajakan VCD yang tersebar di daerah, bahkan disepanjang jalan banyak ditemui penjual VCD bajakan $^{16 .}$

Kepolisian Negara Republik Indonesia memiliki tugas pokok untuk menegakkan hukum sebagaimana yang tertuang dalam Undang-undang Republik Indonesia Nomor 2 Tahun 2002. Tugas pokok ini tercantum jelas di dalam pasal 13 undang-undang tersebut, yang isinya adalah: (1) memelihara keamanan dan ketertiban masyarakat, menegakkan hukum, (3) memberikan perlindungan, pengayoman, dan pelayanan kepada masyarakat. Undang-undang Republik Indonesia Nomor 28 Tahun 2014 tentang Hak Cipta mengatur masalah Penyidikan pada Bab XVI pasal (Penyidikan) dikatakan dalam Pasal 110 ayat (1) menyebutkan bahwa Selain penyidik pejabat Kepolisian Negara Republik Indonesia, Pejabat Pegawai Negeri Sipil tertentu di lingkungan kementerian yang menyelenggarakan urusan pemerintahan di bidang hukum diberi wewenang khusus sebagai penyidik sebagaimana dimaksud dalam Undang-Undang yang mengatur mengenai hukum acara pidana untuk melakukan penyidikan tindak pidana Hak Cipta dan Hak Terkait (2) Penyidik 
sebagaimana dimaksud pada ayat (1) berwenang melakukan:

a. pemeriksaan atas kebenaran laporan atau keterangan berkenaan dengan tindak pidana di bidang Hak Cipta dan Hak Terkait;

b. pemeriksaan terhadap pihak atau badan hukum yang diduga melakukan tindak pidana di bidang Hak Cipta dan Hak Terkait;

c. permintaan keterangan dan barang bukti dari pihak atau badan hukum sehubungan dengan tindak pidana di bidang Hak Cipta dan Hak Terkait;

d. pemeriksaan atas pembukuan, pencatatan, dan dokumen lain berkenaan dengan tindak pidana di bidang Hak Cipta dan Hak Terkait;

e. penggeledahan dan pemeriksaan di tempat yang diduga terdapat barang bukti, pembukuan,pencatatan, dan dokumen lain yang berkenaan dengan tindak pidana di bidang Hak Cipta dan Hak Terkait;

f. penyitaan dan/atau penghentian peredaran atas izin pengadilan terhadap bahan dan barang hasil pelanggaran yang dapat dijadikan bukti dalam perkara tindak pidana di bidang Hak Cipta dan Hak Terkait sesuai dengan Kitab
Undang-Undang Hukum Acara Pidana.

Undang-undang ini mengindikasikan bahwa pada tahapan penyidikan ini dapat dikatakan bahwa tindak pidana ini telah terjadi. Keberadaan pengedar atau penjual VCD bajakan sendiri merupakan wujud kejahatan terhadap Hak Cipta, yang mana kejahatan ini melibatkan serangkaian tindakan melawan hukum melalui perbuatan menjual, memperbanyak, menyiarkan, ataupun mengedarkan.

Pada undang-undang Nomor 28 Tahun 2014 tentang Hak Cipta, kejahatan penjual VCD bajakan ini bukan merupakan kejahatan delik aduan, melainkan delik formil. Kejahatan Hak Cipta terdiri dari unsur pelaku, motif, alat yang digunakan, waktu, tempat, korban, pemasaran, sifat dan ciri-cirinya seperti menyerupai sebagian atau seluruhnya sebagaimana yang telah terdaftar di Ditjen HKI, kualitasnya rendah, dan harganya lebih murah ${ }^{17}$.

Dengan demikian, penyidikan tindak pidana pada kasus VCD bajakan ini tidak memerlukan adanya laporan pengaduan terlebih dahulu, artinya penyidik Polri dapat melakukan proses penyidikan 
berdasarkan temuan yang dilakukan.

Kondisi ini memungkinkan aparat penegak hukum untuk langsung melakukan proses penyidikan ketika menemukan VCD bajakan yang beredar dan diperjualbelikan di masyarakat. Tetapi, pada kenyataannya seringkali proses penegakan hukum tersebut hanya menyentuh kalangan penjual. Polri masih dinilai belum maksimal dalam melakukan penegakan hukum sampai ke hilir dari alur kejahatan VCD bajakan ini.

Penegakan hukum ini belum maksimal menunjukkan bahwa kejahatan VCD bajakan ini semakin meluas di masyarakat. Polri seakanakan kesulitan untuk mengungkap peranan distributor dari penjual yang sebagian besar merupakan pedagang kaki lima.

\subsection{Faktor - Faktor Yang Mempengaruhi Maraknya Jual} Beli VCD Bajakan Di Kabupaten Labuhanbatu Utara

Kemajuan teknologi secara nyata telah memberikan dampak pada berkembangnya kejahatan Hak Cipta khususnya dalam hal penjualan VCD bajakan ini. Pelanggaran hak cipta dapat ditemui dalam setiap kegiatan masyarakat seperti berbagai transaksi jual beli hak cipta bajakan antar produsen dan konsumen dengan harga yang sangat murah jika dibandingkan dengan produk yang memiliki lisensi. Sehingga hal ini menjadi hambatan dalam melakukan penegakan hukum tindak pidana hak cipta. Secara umum ada beberapa faktor yang mempengaruhi penyidikan tindak pidana hak cipta yaitu:

\section{Faktor Aparat Penegak Hukum}

Kepolisian adalah aparat terdepan yang "membentengi" kejahatan Hak Cipta, yang mana hal itu terjadi semenjak UndangUndang Hak Cipta dijadikan delik biasa $^{18}$. Sehingga Kepolisian bisa bertindak tanpa harus ada laporan mana masyarakat. Hambatan yang terjadi di lapangan adalah keseriusan aparat penegak hukum untuk mau menegakkan Undangundang Hak Cipta, karena dari hasil observasi, Kepolisian Kabupaten Labuhanbatu Utara tidak serius menangangi pelanggaran hak cipta yang mana pda jarak 800 meter dari Kantor Kepolisian Kabupaten Labuhanbatu Utara terdapat pengedar VCD bajakan yang 
dimiliki oleh yang berinisial RD.

Penjual VCD bajakan ini tetap berjualan walaupun aparat kepolisian selalu melintasi kedai VCD bajakan beliau dan tidak mungkin aparat kepolisian tidak satupun melihat adanya praktek jual beli VCD bajakan. Jadi yang menjadi faktor utama tidak diberantasnya tindak pidana pengedar dan penjual VCD bajakan adalah tidak adanya kemauan dan keseriusan dari aparat kepolisian di wilayah Kabupaten Labuhanbatu Utara.

Hal yang menjadikan semakin sulitnya penegakan hukum tindak pidana terhadap pengedar dan penjual VCD bajakan ialah adanya Oknum dari aparat Kepolisan yang menjadi backing para pengedar dan penjual VCD bajakan. Faktor oknum dari aparat penegak hukum ini merupakan faktor yang merupakan menjadi penyebab sulitnya Kepolisian Resort Kabupaten Labuhanbatu Utara dapat memberantas tindak pidana terhadap pengedar dan penjual VCD bajakan, dimana oknum yang dimaksud ialah anggota Kepolisian yang menjadi backing para pengedar dan penjual VCD sehingga memberi rasa aman pada pelaku untuk tetap menjual barang hasil pelanggaran Hak Cipta di wilayah hukum Kepolisian Resort Kabupaten Labuhanbatu Utara karena mereka merasa tidak akan ada yang menangkap mereka walaupun perbuatan itu merupakan tindak pidana karena mereka dilindungi oleh oknum Kepolisian.

$$
\text { Hasil }
$$

wawancara

menunjukkan bahwa oknum Kepolisian Kabupaten Labuhanbatu Utara memperoleh keuntungan dengan adanya para pengedar dan penjual VCD bajakan dengan jalan diberikan setoran ataupun sekedar diberikan uang rokok sehingga susah untuk menegakkan Undang-Undang Nomor 28 tahun 2014 tentang Hak Cipta.

Belum terciptanya koordinasi secara intensif dengan Korwas PPNS, sehingga proses penyidikan tindak pidana hak cipta yang dilakukan oleh PPNS Hak Cipta atas perkara hak cipta yang dilaporkan diselesaikan melalui pengadila niaga dan akhirnya kasus di $\mathrm{SP}_{3}$, padahal ketentuan dan kedudukan Polri sebagai Korwas PPNS sangat jelas, dan keberadaan tersebut sesngguhnya dapat memudahkan proses 


$\begin{array}{lll}\text { penegakan } & \text { hukum } & \text { dalam } \\ \text { menangani } & \text { kejahatan } & \text { VCD } \\ \text { bajakan. } & & \end{array}$

\section{Faktor Masyarakat}

Faktor

penghambat berikutnya sehingga sulit ditegakkannya tindak pidana terhadap pengedar dan penjual VCD bajakan adalah faktor masyarakat yakni bagaimana masyarakat itu sendiri menyadari bahwa menjual dan mengedarkan VCD adalah perbuatan yang melanggar hukum dan bisa dikenai sanksi pidana, Dari hasil wawancara diperoleh mengenai pengetahuan mereka akan perbuatan mengedarkan dan menjual VCD bajakan. Masyarakat sebenarnya sudah mengetahui bahwa perbuatan mengedarkan dan menjual VCD bajakan adalah perbuatan pelanggaran hukum, akan tetapi masyarakat tetap bertahan melakukan perbuatan pelanggaran Hak cipta dengan alasan ekonomi yaitu demi bertahan hidup karena susahnya mencari pekerjaan dan daripada mereka mencuri atau melakukan perbuatan kriminal lainnya, makanya masyarakat lebih memilih untuk mengedarkan dan menjual VCD bajakan. Tingkat pendapatan masyarakat yang rendah dan tingkat pengangguran yang tinggi membuat masyarakat berupaya untuk menambah pendapatannya dengan menjual VCD bajakan.

\section{Faktor Ekonomi}

Masyarakat sebagai konsumen dari produk hak cipta bajakan yang masih menggunakan produk bajakan karena harganya yang relatif murah jika dibandingkan membeli produk yang original, sehingga menyebabkan semakin maraknya pelanggaran hak cipta. Keberadaan masyarakat yang justru lebih memilih membeli barang bajakan daripada yang original memberikan pengaruh besar dalam penyidikan, karena semakin banyak permintaan konsumen maka alur perdagangan VCD bajakan akan semakin meningkat.

Hasil wawancara yang dilakukan kepada masyarakat menunjukkan bahwa masyarakat tidak mengetahui bahwa jika mereka membeli VCD bajakan dapat dikenakan sanksi pidana. Masyarakat beranggapan bahwa dengan membeli VCD bajakan, mereka dapat menikmati musik yang mereka sukai. Harga VCD bajakan yang jauh lebih murah 
dibandingkan dengan VCD

original menjadi alasan mereka untuk lebih memilih membeli barang palsu.

\section{Faktor Sosial Budaya}

Secara sosial budaya, masyarakat Indonesia belum terbiasa untuk membeli produkproduk asli, terutama produk industri dari hasil rekaman. Hal ini juga didukung dengan kebudayaan masyarakat Indonesia yang dalam membeli produk hanya berorientasi pada harga barang tanpa melihat kualitas dari barang mereka tersebut ${ }^{19}$.

Wawancara yang dilakukan kepada masyarakat diperoleh bahwa mereka tidak mengutamakan kualitas VCD bajakan yang mereka beli, mereka hanya ingin mendengarkan karya musik saja. Kualitas gambar dan suara tidak masalah bagi mereka. Masyarakat berpendapat bahwa mereka lebih memilih membeli VCD bajakan dengan harga murah karena bisa mendapatkan banyak keping VCD daripada harus membeli VCD asli dengan harga yang mahal tetapi hanya mendapat 1 keping saja.
Bidang sosial budaya ini, dampak yang timbul dari semakin meluasnya pembajakan tersebut begitu beragam. Bagi para pelaku tindak pidana atau para pembajak. keadaan yang berlarut-larut tanpa ada tindakan, akan semakin menimbulkan sikap bahwa pembajakan sudah merupakan hal yang biasa dan tidak lagi merupakan tindakan melanggar Undang-undang.

\section{Faktor Pendidikan}

Masyarakat selama ini kurang mendapatkan sosialisasi terhadap adanya Undang-Undang Hak Cipta. Hal ini mengakibatkan masyarakat melakukan berbagai pelanggarn Hak Cipta akibat tidak mengetahui ketentuan yang tercantum dalam Undang-Undang tersebut ${ }^{20}$. Wawancara dengan masyarakat didapatkan bahwa mereka belum pernah mendapatkan sosialisasi dari penegak hukum Kepolisian Resort Kabupaten Labuhanbatu Utara tentang undang-undang Hak Cipta. Seandainya pihak aparat kepolisian memberikan sosialisasi kepada masyarakat, maka mereka akan berusaha untuk mematuhinya apalagi kalau memang ada 
tindakan tegas dari aparat

kepolisian jika masyarakat yang mengedarkan, menjual, dan membeli VCD bajakan akan dikenanakan sanksi pidana dan perdata.

Tujuannya lainnya ialah agar masyarakat sadar bahwa selain diancam hukuman pidana, perbuatan ini juga merugikan keuangan negara. Dengan jalan diberikan penyuluhan maka diharapkan dapat menyadarkan para pengedar dan penjual sehingga tidak menjual kaset DVD dan VCD bajakan melainkan lebih memilih menjual kaset yang original $^{21}$.

Dampak atas ketidaktahuan masyarakat tentang Undangundang Hak Cipta sehingga masyarakat tidak bisa membedakan antara VCD asli dengan palsu/bajakan, karena pembajakan VCD dikemas mirip dengan VCD yang aslinya baik cover maupun isinya.

\section{Pelayanan Penjual VCD}

Faktor pelayanan juga berpengaruh bagi maraknya pembajakan VCD. Penjual VCD bajakan memberikan pelayanan lebih ke konsumennya. Konsumen boleh menukarkan VCD jika terjadi kerusakan dengan VCD bajakan lainnya tanpa dimintai biaya. Hal ini berbeda dengan pelayanan penjual VCD resmi/asli ${ }^{22}$.

Kutipan wawancara yang dilakukan kepada penjual VCD bajaka adalah Penjual VCD bajakan memang memberikan pelayanan tukar VCD yang rusak dengan VCD bajakan lainnya demi menarik minat pelanggan agar tetap setia membeli di kedai mereka. Batas waktu untuk mengembalikan VCD bajakan yang rusak adalah 1 minggu setelah pembelian.

\section{Rendahya Sanksi Hukum}

Sanksi Hukum yang diterapkan pembajakan VCD hanya diterapkan pada pembajak saja, belum menerapkan pada konsumen yang membeli VCD bajakan. Selama ini penegakan hukum dibidang hak cipta, khususnya karya musik berupa VCD belum berlaku secara menyeluruh. Apabila mengacu pada Undang-undang Hak Cipta, maka sanksi yang ditekankan kepada pembajak hanya bersifat 
denda dan belum mengarah pada pidana.

Maraknya kejahatan pelanggaran hak cipta tersebut juga tidak terlepas dari kemauan masyarakat untuk mendapatkan barang yang sama dengan harga yang murah, maka mereka pasti akan mencari barang-barang bajakan yang otomatis mempunyai harga jual yang lebih murah apabila dibandingkan dengan produk aslinya. Mengenai produkproduk bajakan tersebut tidak hanya harganya saja yang murah akan tetapi akses mendapatkannya juga mudah, hal ini ditandai dengan banyaknya penjual yang menjual DVD,VCD, Tape Cassete dan CD Game bajakan dipinggirpinggir jalan maupun dalam MallMall besar, hal ini justru mengakibatkan produsen rekaman ataupun pelaku hak cipta mengalami kerugian baik kerugian materil maupun kerugian immateril, yang secara tidak langsung juga telah merugikan negara karena telah mengurangi pemasukkan negara dari penjualan barang-barang yang legal ${ }^{23}$.

Besarnya jumlah kerugian yang dialami oleh industri maupun yang dialami oleh negara terhadap kejahatan hak cipta tersebut tidak boleh dipandang sepele oleh penegak hukum, sebagai wujud konkrit keinginan untuk memberantas kejahatan hak cipta tersebut berusaha untuk meningkatkan perlindungan bagi pencipta maupun pemegang hak cipta tersebut.

Sanksi terhadap pelanggaran hak cipta sangat berat akan tetapi kejahatan terhadap hak cipta juga terus terjadi (seperti maraknya penjualan VCD,DVD, Kaset atau CD Game bajakan) di pasaran, hal tersebut dapat terjadi dikarenakan kurangnya kinerja aparat atau masih lemahnya instrumen hukum yang mengatur hak cipta tersebut ${ }^{24}$.

Sosialisasi masyarakat khususnya pengedar dan penjual, yang mana tujuannya agar masyarakat sadar bahwa menjual dan mengedarkan VCD bajakan merupakan perbuatan yang melanggar Undang-Undang dan diancam dengan hukuman 5 tahun penjara dan denda 5 ratus juta rupiah. Pelaku tindak pidana pelanggaran Hak Cipta ini tidak terbatas pada subjek hukum per 
orang (naturlijke person) tapi juga

subjek hukum bukan orang (recht person) bahkan recht person tersebut sudah membentuk jaringan (sindikat) yang sangat luas dan cermat. Karena itu, kejahatan terhadap Hak Cipta sering dikategorikan sebagai kejahatn terorganisir (organized crime). Hal ini mengingat subjek pelaku kejahatan terhadap Hak Cipta khususnya penjualan VCD bajakan ini dijalankan dengan cara atau modus operandi yang rapih dan mengikutsertakan entitas yang terputus atau yang disebut dengan Modus Operandi ${ }^{25}$.

\section{Kurangnya Dana Operasional}

Hal yang menjadi faktor penghambat penegakan hukum terhadap pelaku tindak pidana pengedar dan penjual VCD bajakan diwilayah hukum Kepolisian Resort Kabupaten Labuhanbatu Utara ialah dari segi kurangnya dana operasional, dimana dana operasional untuk melakukan razia rutin tidak disediakan secara khusus namun menggunakan dana operasional bulanan yang ada di Kepolisian Resort Kabupaten Labuhanbatu Utara.
Pengusutan kasus VCD bajakan tidak mudah dilakukan karena membutuhkan biaya operasional yang cukup besar. Berdasarkan hasil wawancara dengan pihak kepolisian, untuk razia rutin dana tidak memadai dan ketika dilakukan penangkapan terhadap pelaku dan pengedar VCD bajakan maka pihak polisi harus mencari tahu asal barang itu dikirim dan nama pengirimnya. Untuk mengetahui VCD itu bajakan atau asli, maka pihak kepolisian perlu mendatangkan ahli yang hanya ada di Jakarta dan untuk melakukan hal ini pihak kepolisian membutuhkan dana yang besar untuk dapat mengungkap tindak pidana ini secara keseluruhan.

Tindakan represif dalam melakukan operasi rutin terhadap para pengedar dan penjual VCD bajakan memerlukan dana operasional yang cukup besar karena luasnya wilayah Kabupaten Labuhanbatu Utara yang akan ditelusuri untuk menemukan dan menindak para pelaku tindak pidana pengedar dan penjual VCD bajakan. 


\section{KESIMPULAN DAN SARAN}

\subsection{Kesimpulan}

1) Peranan kepolisian dalam penegakan hukum terhadap tindak pengedar dan penjual VCD bajakan di wilayah hukum Polisi Resort Kabupaten Labuhanbatu Utara belum berjalan sebagaimana mestinya dan masih jauh dari harapan, hal ini bisa dilihat adanya "Pembiaran “ oleh Pihak Kepolisian padahal letak toko kaset yang menjual VCD bajakan diwilayah hukum Polisi Resort Kabupaten Labuhanbatu Utara tidak jauh dengan kantor Polisi setempat. Penegakan hukum terhadap tindak pidana pengedar dan penjual VCD bajakan di wilayah hukum Polisi Resort Kabupaten Labuhanbatu Utara tidak bisa berjalan sebagaimana mestinya disebabkan adanya beberapa hambatan yang menyebabkan sulitnya tindak pidana ini ditegakkan dan tidak adanya keseriusan dari pihak Kepolisian.

2) Faktor yang mempengaruhi maraknya pengedar dan penjualan VCD bajakan adalah faktor aparat penegak hukum yan tidak serius menangani kasus pelangaran hak cipta, faktor masyarakat yang lebih memilih mengedarkan dan menjual VCD bajakn karena sulitnya mendapatkan pekrjaan, faktor ekonomi yang mana masyarkat lebih suka membeli VCD bajakan dibandingkan VCD original karena hrganya yang relatif lebih murah. Tidak adanya sosialisasi kepada masyarakat tida jika mereka membeli VCD bajakan maka mereka akan terkena sanksi pidana karena telah melanggar Hak cipta serta Sanksi Hukum yang diterapkan pembajakan VCD hanya diterapkan pada pembajak saja, belum menerapkan pada konsumen yang membeli VCD bajakan.

\subsection{Saran}

1) Penegak hukum wajib melakukan sosialisasi secara rutin kepada masyarakat tentang Undangundang nomor 28 Tahun 2014 tentang Hak Cipta Karya Musik agar masyarakat memahami jika menjual, membeli VCD bajakan merupakan perbuatan yang mengakibatkan kerugian negara dari sektor pajak serta tindak kriminal yang serius karena telah melanggar Hak Cipta Karya Musik dan kepada masyarakat sebagai pembeli jika mereka membeli VCD bajakan akan dikenakan sanksi pidana dan perdata karena 
telah melanggar ketentuan hukum yang mengatur tentang Hak Cipta.

2) Perlunya peranan masyarakat luas untuk membantu penegak hukum dalam mengatasi masalah pelanggaran hak cipta tentang jual beli kaset VCD Bajakan yang semakin merajalela dan penegak hukum harus tegas dalam melaksanakan amanah dari undang-undang hak cipta yang tujuannya menjamin perlindungan hukum yang lebih baik untuk para penciptanya agar tercapainya 3 Tujuan Hukum yaitu kepastian hukum, Kemanfaatan dan keadilan.

\section{DAFTAR PUSTAKA}

\section{Buku}

Abdul Rasyid Saliman, et.al, 2007. Hukum Bisnis untuk Perusahaan :Teori dan Contoh Kasus, Jakarta: Kencana.

Chazani, Adami. 2007. Tindak Pidana Hak Atas Kekayaan Intelektual (HAKI). Malang: Bayumedia.

Isnaini, Yusran. 2009. Hak Cipta dan Tantangannya di Era Cyber Space. Bogor: Ghalia Indonesia.

Kusmawan Denny. 2014. Perlindungan Hak Cipta Atas Buku. Jurnal Perspektif.

M. Solly Lubis , 1994, Filsafat Ilmu dan penelitian, mandar maju, Bandung.

Nitisbakara.Ronny. 2004. Ketika Kejahatan Berdaulat. Jakarta: Grafindo.
Oloan sitorus dan darwinsyah minim, 2005, Membangun Teori hukum indonesia, Mitra kebijakan tanah indonesia, Yokyakarta.

RE. Baringbing. 2001. Catur Wangsa Simpul Mewujudkan Supremasi Hukum, Jakarta: Pusat Kajian Informasi.

Soerjono seokanto, 1986, Pengantar penelitian hukum, UI Press

Supanto. 2000. Kebijakan Hukum Pidana dalam Rangka Penanggulangan Tindak Pidana di Bidang Hak Kekayaan Intelektual. Universitas Diponegoro.

Widyodarmono. 2002. Tindak Pidana Hak Cipta Analisis dan Penyelesaiannya. Jakarta: Sinar Grafika.

\section{Undang- undang}

Undang -undang Dasar tahun 1945

Undang-Undang Hak Cipta Nomor 28 Tahun 2014 Hak atas Kekayaan Intelektual

\section{Jurnal}

Kusno, Habi. 2016. Perlindungan Hukum Hak Cipta Terhadap Pencipta Lagu yang Diunduh Melalui Internet. Jurnal Fiat Justicia.

Thalib Prawitri. 2013. Perlindungan HukumTerhadap Pemegang Hak Cipta dan Pemilik Lisensi Rekaman Berdasarkan Undang-undang TentangHak Cipta. Jurnal Yuridika.

\section{Internet}

http://www.beritabojonegoro.com. https://www.google.com/search?q=pendapat + para+ahli+tentang+teori+keadilan https://www.google.com/search?q=pendapat+ para+ahli+tentang+teori+keadilan, http://www.Ferli1982.wordpress.com. http://www.beritabojonegoro.com. 
